\title{
Effect of low and high temperatures on the photosynthetic performance of Lantana camara L. Leaves in...
}

Article in Russian Journal of Plant Physiology · May 2013

DOI: $10.1134 /$ S1021443713030047

CITATION

1

5 authors, including:

\section{J. Carrión-Tacuri}

Dirección del Parque Nacional Galápagos

8 PUBLICATIONS 38 CITATIONS

SEE PROFILE

\section{Enrique Figueroa}

Universidad de Sevilla

110 PUBLICATIONS 2,320 CITATIONS

SEE PROFILE
READS

97

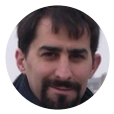

A. E. Rubio-Casal

Universidad de Sevilla

32 PUBLICATIONS 476 CITATIONS

SEE PROFILE

Jesus M. Castillo

Universidad de Sevilla

62 PUBLICATIONS 1,052 CITATIONS

SEE PROFILE

Some of the authors of this publication are also working on these related projects:

Homeostasis de Cloruro en Plantas View project

Galapagos National Park Directorate. Managing environmental quality rules and all research projects in

Project the Galapagos Islands. View project 


\title{
RESEARCH
} PAPERS

\section{Effect of Low and High Temperatures on the Photosynthetic Performance of Lantana camara $\mathbf{L}$. Leaves in Darkness ${ }^{1}$}

\author{
J. Carrión-Tacuri, A. E. Rubio-Casal, A. de Cires, M. E. Figueroa, and J. M. Castillo \\ Departamento de Biología Vegetal y Ecología, Universidad de Sevilla, Ap. 1095, 41080 Sevilla, Spain; \\ fax: +34+954-61-5780; e-mail: jorgecarrion@us.es
}

Received May 24, 2012

\begin{abstract}
Low and high temperatures are known as most important factors influencing plant performance and distribution. Plants of Lantana camara L. coming from two distinct geographical populations (Iberian Peninsula and Galápagos Islands) were cultivated in a common garden experiment, and their leaves were subjected to thermal treatments (from +20.0 to $-7.5^{\circ} \mathrm{C}$ during the winter and from +20.0 to $+50.0^{\circ} \mathrm{C}$ during the summer) in a programmable water bath in darkness. Their photosynthetic performance and their recovery capacity after the thermal treatment were evaluated by measuring chlorophyll fluorescence, net photosynthesis rate, and leaf necrosis. In general, L. camara photosynthetic apparatus showed a wide range of temperature tolerance in darkness, showing optimal functioning of its photosystem II just after exposure to temperatures between -2.5 and $+35.0^{\circ} \mathrm{C}$ for the Iberian population and between +10.0 and $+25.0^{\circ} \mathrm{C}$ for the Galápagos population. Just after exposure to low and high temperatures, gradual cold and heat-induced photoinhibition was recorded for both populations. After $24 \mathrm{~h}$, leaves of $L$. camara demonstrated a great recovery capacity from -2.5 to $+42.5^{\circ} \mathrm{C}$. However, leaves of the treatments from $-5.0^{\circ} \mathrm{C}$ down and $+47.50^{\circ} \mathrm{C}$ up showed permanent damages to the photosynthetic apparatus and to the leaf tissues. Slight interpopulation differences were found only at extreme temperatures.
\end{abstract}

Keywords: Lantana camara, Galápagos, Iberian Peninsula, necrosis, net photosynthesis, photoinhibition, recovery capacity, thermal tolerance

DOI: $10.1134 / \mathrm{S} 1021443713030047$

\section{INTRODUCTION}

Low and high air temperatures are known as most important factors influencing plant performance and distribution. In a changing world with increasing environmental temperatures that can alter distribution of existing invasive species [1], the knowledge of the effects of low and high temperatures on weeds can be used to predict their behavior and as a tool allowing us to identify sensible habitats to invasions.

Optimum temperatures for photosynthesis exhibited by a plant species reflect the environmental temperature range, to which the species has genetically and physiologically been adapted [2]. When plants are exposed to temperatures above or below their optimum physiological range, their photosynthetic performance becomes affected [3]. Thus, extreme temperatures can inhibit photosynthesis in many different ways, such as decreasing the efficiency of photosystem II (PSII), limiting enzymatic rates of the Calvin cycle,

\footnotetext{
${ }^{1}$ This text was submitted by the authors in English.
}

Abbreviations: $F_{0}$-basal fluorescence; $F_{\mathrm{m}}$-maximum fluorescence; $F_{\mathrm{v}} / F_{\mathrm{m}}$-maximum quantum efficiency of PSII photochemistry; $P_{\mathrm{N}}$ - net photosynthesis rate; PSII-photosystem II. altering photorespiration, or changing the structure of thylakoids [4, 5].

Extreme temperature effects on photosynthesis can occur in darkness, for example, during cold nights [6], and they are aggravated when plants are exposed to high levels of irradiance [7]. In this context, interspecific difference in temperature tolerance can be recorded.

Lantana camara L. (Verbenaceae) has been classified between the most invasive species around the world, in tropical and subtropical regions worldwide between $35^{\circ} \mathrm{N}$ and $35^{\circ} \mathrm{S}$ [8]. It has been described that in the field L. camara grows actively at temperatures above $+15^{\circ} \mathrm{C}$ [9], being susceptible to frosts and low temperatures; so it seldom occurs in places where temperatures frequently fall below $+5^{\circ} \mathrm{C}$ [10], where its branches and leaves die and its growth ceases [11]. Nevertheless, no study is available about the specific effects of temperature on L. camara photosynthetic apparatus.

The aims of this work were to analyze the effects of low and high temperatures on the photosynthetic performance of $L$. camara leaves in darkness to identify the lowest and the highest temperature limits, at which its leaves are able to resist during nighttime and to know if two populations of L. camara coming from 
contrasted latitudes show different response to temperature. With these aims, we evaluated in a common garden experiment the photosynthetic performance and the recovery capacity after high and low temperature treatments for L. camara plants coming from the Galápagos Archipelago and from the Southwest of Iberian Peninsula. We hypothesized: (1) the photosynthetic apparatus of $L$. camara would be sensible to temperature lower than $+5^{\circ} \mathrm{C}$, and (2) L. camara from the Iberian Peninsula would have a higher tolerance to extreme temperatures than the population from the Galápagos Islands since Iberian populations are exposed to more extreme temperatures during summer and winter than the Galápagos populations.

\section{MATERIALS AND METHODS}

Plant material. Two wild Lantana camara L. populations were studied, one from the center of the L. camara latitudinal geographic distribution at the Galápagos Archipelago (from the Transition Zone (ca. $120 \mathrm{~m}$ above sea level) in Santa Cruz Island, $0^{\circ} 42^{\prime} \mathrm{S}$; $90^{\circ} 19^{\prime} \mathrm{W}$ ) and another from the northern extreme of its geographic distribution at Southwest of Iberian Peninsula (Asperillo Sea Cliff, Huelva, $37^{\circ} 06^{\prime} \mathrm{N}$; $6^{\circ} 46^{\prime} \mathrm{W}$ ). At both locations, L. camara was originally coming from gardens, arriving in 1938 for first time in the Galápagos [12] and probably during the seventies or eighties after the construction of Parador de Mazagón in 1968 on the Asperillo Sea Cliff.

Two distinct seasons can be differentiated over the year in the Galápagos Islands: during the warm-wet season (January to June) mean daily air temperature is between +25 and $+26^{\circ} \mathrm{C}$ and during the cool-dry season (July to December) temperature is between +18 and $+26^{\circ} \mathrm{C}$ [13]. The Southwest of Iberian Peninsula is under Mediterranean climate modified by oceanic influence with wet winters (January mean temperature is of $+11^{\circ} \mathrm{C}$ with minimum of ca. $0^{\circ} \mathrm{C}$; frost does not occur in most years) and warm and sunny summers (August mean temperature is of $+25^{\circ} \mathrm{C}$; rarely maximum temperatures exceeds $+40^{\circ} \mathrm{C}$ ) [14].

Seeds were collected from 10 plants chosen randomly in each population. 10 plants of each population were cultivated in plastic pots in peat soil at the open-air area of the greenhouse facilities of the University of Seville during 4 months.

Controlled-temperature experiment. The youngest fully expanded leaf was used to avoid possible effects related to ontogenetic leaf development since it might affect the temperature sensitivity. Leaves collection $(n=5$ leaves per treatment and population chosen randomly from different individuals) for low-temperature experiment was carried out at sunrise on the 21st February 2011 and for high temperature experiment on the 22nd June 2011, so the plants were acclimated to winter and summer conditions, respectively.

Average daily temperature during the month previous to collection in winter was $+11.4 \pm 0.5^{\circ} \mathrm{C}$, with a maximum momentary temperature of $+24.9^{\circ} \mathrm{C}$ and a minimum of $+0.9^{\circ} \mathrm{C}$, while in summer it was $+26.0 \pm$ $0.6^{\circ} \mathrm{C}$, with $+40.4^{\circ} \mathrm{C}(\max )$ and $+12.9^{\circ} \mathrm{C}$ (min) (www.meteored.com). After collection leaves were immediately stored in a saturated humidity atmosphere at $+20^{\circ} \mathrm{C}$ during $3 \mathrm{~h}$.

Leaves were placed individually in sealed plastic bags and immersed in a programmable water bath (Neslab RTE-200, NESLAB Instr., United States) for $30 \mathrm{~min}$ in darkness [15]. Ethylene glycol 30\% (v/v) was used to avoid ice crystal formation in the water bath. Every leaf was immersed at the same time in the water bath at $+20.0^{\circ} \mathrm{C}$.

During the low-temperature experiment, temperature was decreasing gradually from +20.0 to $0^{\circ} \mathrm{C}$ with steps of $5.0^{\circ} \mathrm{C}$ and from 0.0 to $-7.5^{\circ} \mathrm{C}$ with steps of $2.5^{\circ} \mathrm{C}$. The exposure to low temperatures in darkness would correspond with the conditions experienced by leaves during nocturnal chilling episodes, such as those recorded at $L$. camara northern and southern extremes of its geographical distribution range and at high altitudes all across its geographical distribution. During the high-temperature experiment, temperature was increasing gradually from +20.0 to $+40.0^{\circ} \mathrm{C}$ with steps of $5.0^{\circ} \mathrm{C}$ and from +40.0 to $+50.0^{\circ} \mathrm{C}$ with steps of $2.5^{\circ} \mathrm{C}$. The exposure to high temperature in darkness would correspond with the conditions experienced by $L$. camara leaves during some summer nights at the Southwest Iberian Peninsula $\left(\right.$ ca. $\left.+30^{\circ} \mathrm{C}\right)$. After $30 \mathrm{~min}$ in each thermal treatment, chlorophyll $a$ fluorescence was recorded in a dark room to not disrupt the dark-adapted state of leaves.

To assess the recovery capacity of the photosynthetic apparatus, leaves were kept in saturated humidity, $+20^{\circ} \mathrm{C}$ and exposed to ca. $40 \mu \mathrm{mol} /\left(\mathrm{m}^{2} \mathrm{~s}\right)$ during $24 \mathrm{~h}$ [15]; these conditions of low-light intensity favor the substitution of damaged proteins of the PSII. A period of milder temperatures is required to return to rates of photosynthesis as those prior to the extreme temperature event [6]. After the recovery period, necrosis percentage was measured as the proportion of the total leaf area. Chlorophyll $a$ fluorescence fast dynamic and net photosynthesis rate were also recorded.

Chlorophyll fluorescence. Chlorophyll $a$ fluorescence measurements were carried out in dark-adapted leaves (at least during $30 \mathrm{~min}$ ) using a FMS-2 portable modulated fluorimeter (Hansatech Instr., United Kingdom) on the adaxial leaves surface. The minimal fluorescence level in the dark-adapted state $\left(F_{0}\right)$ was measured by using a modulate pulse (PPFD < $0.05 \mu \mathrm{mol} /\left(\mathrm{m}^{2} \mathrm{~s}\right)$ for $\left.1.8 \mu \mathrm{s}\right)$ too small to induce significant physiological changes in the plant [16]. The data stored were averages taken over a 1.6-s period. Maximal fluorescence in this state $\left(F_{\mathrm{m}}\right)$ was measured after applying a saturating actinic light pulse of $15000 \mu \mathrm{mol} /\left(\mathrm{m}^{2} \mathrm{~s}\right)$ for $0.7 \mathrm{~s}$ [17]. The value of $F_{\mathrm{m}}$ was recorded as the highest average of two consecutive points. Values of the variable fluorescence $\left(F_{\mathrm{v}}=F_{\mathrm{m}}-F_{0}\right)$ and the maximum 
quantum efficiency of PSII photochemistry $\left(F_{\mathrm{v}} / F_{\mathrm{m}}\right)$ were calculated.

Net photosynthesis. Net photosynthesis rate $\left(P_{\mathrm{N}}\right)$ was measured as $\mathrm{O}_{2}$ evolution using an LD2 Hansatech leaf chamber with a gas phase $\mathrm{O}_{2}$ electrode at $25^{\circ} \mathrm{C}$ $(n=3-5$ leaves per treatment and two measurements in each leaf). A buffer of $1 \mathrm{M}$ carbonate/bicarbonate $(\mathrm{pH} 9.0)$ was used to provide a $\mathrm{CO}_{2}$ saturated atmosphere. Saturating irradiance was provided by an LS2 Hansatech source. Photosynthetic photon flux density (PPFD) was measured using an integrating quantum sensor cell (Li-Cor, $190 \mathrm{SB}$ ).

Statistical analysis. All statistical tests were carried out using the SPSS v. 18 (Statistic Inc.). Data were tested for normality with the Kolmogorov-Smirnov test and for homogeneity of variance with the Levene test. Mean physiological data for the same population at different temperatures were compared using oneway analysis of variance (ANOVA, $F$-test) followed by Tukey's Honest Significant Difference (HSD). When normality or homogeneity of variance was not reached, data were analyzed using Kruskal-Wallis non-parametric analysis of variance, followed by the Mann-Whitney $U$-test to compare means between two treatments. Interpopulation differences at the same temperature were compared using Student $t$-test for independent samples. Deviation was calculated as standard error of mean (SE).

\section{RESULTS}

Chlorophyll Fluorescence Just after Thermal Treatments

$F_{\mathrm{v}} / F_{\mathrm{m}}$ for both populations decreased logarithmically at low temperatures and sigmoidal at high temperatures (Figs. 1a, 1b).

At low temperatures, $F_{\mathrm{v}} / F_{\mathrm{m}}$ for the Iberian population was similar from +20.0 to $-2.5^{\circ} \mathrm{C}$ (ca. 0.770), decreasing significantly at -5.0 and $-7.5^{\circ} \mathrm{C}$ (ca. 0.680) (Kruskal-Wallis, $P<0.01$; Mann-Whitney $U$-test, $P<$ $0.05)$. For the Galápagos population, $F_{\mathrm{v}} / F_{\mathrm{m}}$ was similar from +20.0 to $+10.0^{\circ} \mathrm{C}$ (ca. 0.790$)$, decreasing significantly at $-2.5,-5$ (ca. 0.710$)$, and $-7.5^{\circ} \mathrm{C}(0.550)$ (Kruskal-Wallis, $P<0.01$; Mann-Whitney $U$-test, $P<$ $0.05)$. These decreases in $F_{\mathrm{v}} / F_{\mathrm{m}}$ for both populations were due to a logarithmic drop of $F_{\mathrm{m}}$ and constant levels of $F_{0} . F_{\mathrm{v}} / F_{\mathrm{m}}$ was lower for the Galápagos population than for Mazagón at $-7.5^{\circ} \mathrm{C}$ ( $t$-test, $\left.P<0.05\right)$ (Fig. 1a).

At high temperatures, $F_{\mathrm{v}} / F_{\mathrm{m}}$ for the Iberian population was constant from +20.0 to $+35.0^{\circ} \mathrm{C}$ (ca. $0.870)$, decreasing significantly from $+40.0(0.830)$ to $+50.0^{\circ} \mathrm{C}(0.060)$ (Kruskal-Wallis, $P<0.001$; MannWhitney $U$-test, $P<0.01) . F_{\mathrm{v}} / F_{\mathrm{m}}$ for the Galápagos population was also ca. 0.870 from +20.0 to $+25.0^{\circ} \mathrm{C}$, decreasing significantly from $+30.0^{\circ} \mathrm{C} \quad(0.860)$ onwards and strongly from $+42.5(0.750)$ to $+50.0^{\circ} \mathrm{C}$ (0.060) (Kruskal-Wallis, $P<0.001$; Mann-Whitney $U$-test, $P<0.01)$. These drops in $F_{\mathrm{v}} / F_{\mathrm{m}}$ were due to decreasing $F_{\mathrm{m}}$ together with increasing $F_{0} . F_{\mathrm{v}} / F_{\mathrm{m}}$ was similar for both populations in every treatment ( $t$-test, $P>0.05)$ (Fig. 1b).

\section{Chlorophyll Fluorescence after the Recovery Period}

After the recovery period after low temperatures, both populations showed an exponential drop of $F_{\mathrm{v}} / F_{\mathrm{m}}$ below $-2.5^{\circ} \mathrm{C}$ (Fig. 2a,b). Leaves showed a great recovery capacity from $+20.0^{\circ} \mathrm{C}$ to $-2.5^{\circ} \mathrm{C}$ for both populations, with high and similar $F_{\mathrm{v}} / F_{\mathrm{m}}$ (ca. 0.770 ). Recovery capacity was slightly lower after $-5.0^{\circ} \mathrm{C}$ (ca. 0.590). After $-7.5^{\circ} \mathrm{C}$, leaves showed the lowest $F_{\mathrm{v}} / F_{\mathrm{m}}$ (ca. 0.110 ) (Kruskal-Wallis, $P<0.01$; MannWhitney $U$-test, $P<0.05$ ) coinciding with the lowest $F_{0}$ and Fm (Mann-Whitney $U$-test, $\left.P<0.05\right)$. There were no significant differences in $F_{\mathrm{v}} / F_{\mathrm{m}}$ between populations in any treatment (Fig. 2a).

After the recovery period after high temperatures, leaves of both populations showed similar values of $F_{\mathrm{v}} / F_{\mathrm{m}}$ (ca. 0.860 ) from +20.0 to $+42.5^{\circ} \mathrm{C}$, decreasing significantly after $+45.0^{\circ} \mathrm{C}$ (ca. 0.83 ), $+47.5^{\circ} \mathrm{C}$ (ca. 0.500 ) and $+50.0^{\circ} \mathrm{C}$ (ca. 0.090) (Kruskal-Wallis, $P<$ 0.01 ; Mann-Whitney $U$-test, $P<0.05$ ). The unique difference in $F_{\mathrm{v}} / F_{\mathrm{m}}$ between both populations was recorded after $+47.5^{\circ} \mathrm{C}$, with the Galápagos population showing higher $F_{\mathrm{v}} / F_{\mathrm{m}}$ than the Iberian Peninsula population ( $t$-test, $P<0.05$ ) (Fig. $2 b$ ).

At $+20.0^{\circ} \mathrm{C}$, leaves of both populations acclimated to summer conditions showed the lower photoinhibition levels (higher $F_{\mathrm{v}} / F_{\mathrm{m}}$ ) than leaves acclimated to winter just after the thermal treatment ( $t$-test, $P<$ 0.01 ) and after the recovery period only Galápagos populations maintained that difference $(t$-test, $P<$ $0.001)$. These differences were due to similar $F_{\mathrm{m}}$ for both seasons and slightly higher $F_{0}$ during winter ( $t$ test, $P<0.05$ ) (Figs. 1a, 1b; Figs. 2a, 2b).

\section{Net Photosynthesis Rate}

After the recovery period, $P_{\mathrm{N}}$ for the Iberian population subjected to low temperatures decreased logarithmically, varying between $17.8 \pm 2.2 \mu \mathrm{mol} \mathrm{O} 2 /\left(\mathrm{m}^{2} \mathrm{~s}\right)$ after $+20.0^{\circ} \mathrm{C}$ and $2.9 \pm 0.3 \mu \mathrm{mol} \mathrm{O} \mathrm{O}_{2} /\left(\mathrm{m}^{2} \mathrm{~s}\right)$ after $-7.5^{\circ} \mathrm{C}$ (ANOVA, $F=4.207, P<0.01$ ) (Fig. $\left.3 \mathrm{a}\right) . P_{\mathrm{N}}$ for the Galápagos population subjected to low temperatures decreased also logarithmically, varying between ca. $15 \mu \mathrm{mol} \mathrm{O}_{2} /\left(\mathrm{m}^{2} \mathrm{~s}\right)$ after $+20.0^{\circ} \mathrm{C}$ and $+5.0^{\circ} \mathrm{C}$ to $1.6 \pm 0.2 \mu \mathrm{mol} \mathrm{O}_{2} /\left(\mathrm{m}^{2} \mathrm{~s}\right.$ ) after $-7.5^{\circ} \mathrm{C}$ (ANOVA, $F=$ $16.510, P<0.001$ ). Leaves of $L$. camara from the Galápagos population did not recover after -5.0 and $7.5^{\circ} \mathrm{C}$, showing lower $P_{\mathrm{N}}$ than the other treatments (Tukey's HSD-test, $P<0.05$ ). Instead, leaves from the Iberian population showed a significant lower $P_{\mathrm{N}}$ only after $-7.5^{\circ} \mathrm{C}$ (Fig. 3a).

On the other hand, $P_{\mathrm{N}}$ for leaves of L. camara from both populations decreased sigmoidal at high temperatures. $P_{\mathrm{N}}$ for the Iberian population was similar from +20 to $+42.5^{\circ} \mathrm{C}$ (ca. $15 \mu \mathrm{mol} \mathrm{O} /\left(\mathrm{m}^{2} \mathrm{~s}\right)$ ) and decreased significantly from $11.4 \pm 0.7 \mu \mathrm{mol} \mathrm{O}_{2} /\left(\mathrm{m}^{2} \mathrm{~s}\right)$ ) to 

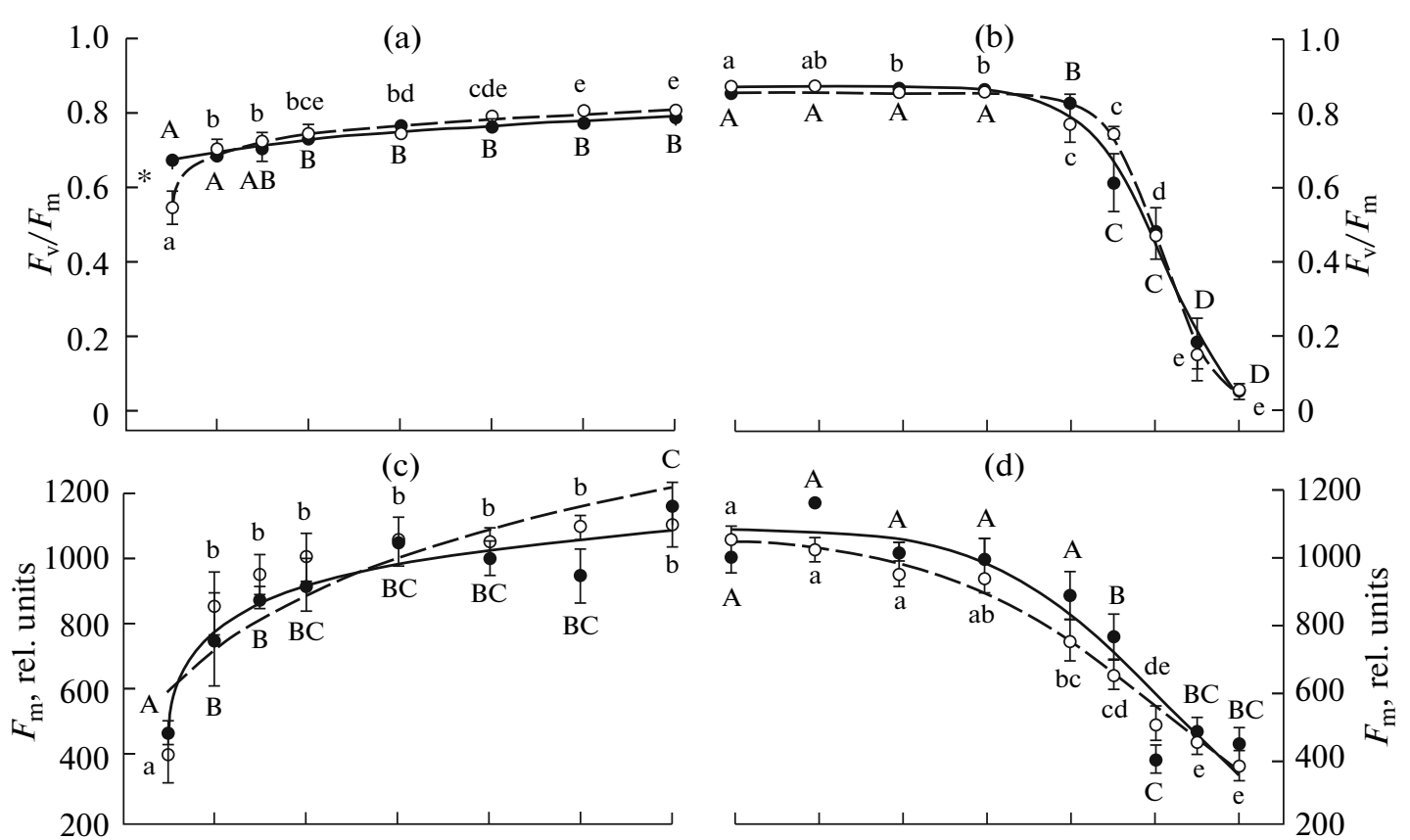

(e)

(f)

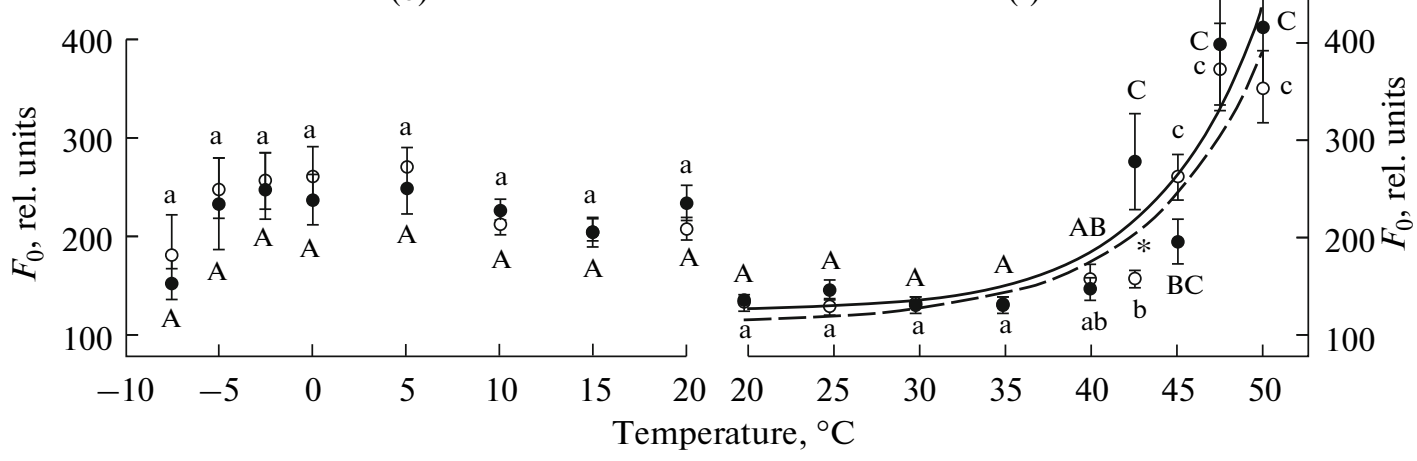

Fig. 1. Maximum quantum efficiency of PSII photochemistry $\left(\left(F_{\mathrm{v}} / F_{\mathrm{m}},(\mathrm{a}, \mathrm{b})\right)\right.$, maximum fluorescence $\left(\left(F_{\mathrm{m}},(\mathrm{c}, \mathrm{d})\right)\right.$, and basal fluorescence $\left(\left(F_{0},(\mathrm{e}, \mathrm{f})\right)\right.$ after $30 \mathrm{~min}$ of treatment from +20.0 to $-7.5^{\circ} \mathrm{C}$ (left panels) and from +20.0 to $+50.0^{\circ} \mathrm{C}$ (right panels) for leaves of $L$. camara from the Galápagos Islands (white symbols; dotted line) and from the Southwest Iberian Peninsula (black symbols; continued line). Different letters denote significant differences between treatments (ANOVA or Kruskal-Wallis, $P<$ 0.05 ) for the same population (Iberian Peninsula: capital letters; Galápagos: lowercase letters) and asterisks denote differences between populations for the same temperature $(t$-test, $P<0.05)$. Data are means $\pm \mathrm{SE}$.

$\left.+50.0^{\circ} \mathrm{C}\left(3.6 \pm 1.2 \mu \mathrm{mol} \mathrm{O} \mathrm{O}_{2} /\left(\mathrm{m}^{2} \mathrm{~s}\right)\right)\right)($ Kruskal-Wallis, $P<0.01$; Mann-Whitney $U$-test, $P<0.05$; Fig. $3 \mathrm{~b})$. Instead, $P_{\mathrm{N}}$ for the Galápagos population was constant from +20.0 to $+47.5^{\circ} \mathrm{C}$ (ca. $15 \mu \mathrm{mol} \mathrm{O}_{2} /\left(\mathrm{m}^{2} \mathrm{~s}\right)$ ), showing lower $P_{\mathrm{N}}$ after $+47.5^{\circ} \mathrm{C}(2.0 \pm 0.4 \mu \mathrm{mol}$ $\left.\mathrm{O}_{2} /\left(\mathrm{m}^{2} \mathrm{~s}\right)\right)$ ) (Kruskal-Wallis, $P<0.05$; Mann-Whitney $U$-test, $P<0.05) . P_{\mathrm{N}}$ was higher for the Galápagos population than for the Iberian population after +40.0 and $+45.0^{\circ} \mathrm{C}$ ( $t$-test, $P<0.05$; Fig. $\left.3 \mathrm{~b}\right)$.

\section{Necrosis}

Leaves from both populations showed necrosis only at temperatures lower than $+5.0^{\circ} \mathrm{C}$, varying from $6 \%$ at $0^{\circ} \mathrm{C}$ to $100 \%$ at $-7.5^{\circ} \mathrm{C}$. The necrosis percentage was significantly higher after $-7.5^{\circ} \mathrm{C}$ than after all treatments except $-5.0^{\circ} \mathrm{C}$ (Kruskal-Wallis, $P<0.05$; Mann-Whitney $U$-test, $P<0.05$ ) (Fig. $3 \mathrm{c}$ ).

Leaves from the Iberian population showed necrosis at $+47.5^{\circ} \mathrm{C}(23 \%)$ and at $+50.0^{\circ} \mathrm{C}(74 \%)$ (KruskalWallis, $P<0.01$; Mann-Whitney $U$-test, $P<0.05)$, while leaves from the Galápagos populations suffered necrosis only at $+50.0^{\circ} \mathrm{C}(88 \%)$ (Kruskal-Wallis, $P<$ 0.01; Mann-Whitney $U$-test, $P<0.01)$ (Fig. $3 \mathrm{~d}$ ).

\section{DISCUSSION}

In field studies, L. camara has been described as a species sensitive to low temperatures, its branches and leaves showing thermal stress symptoms at temperatures lower than $+5.0^{\circ} \mathrm{C}[10,11]$. Nevertheless, its 

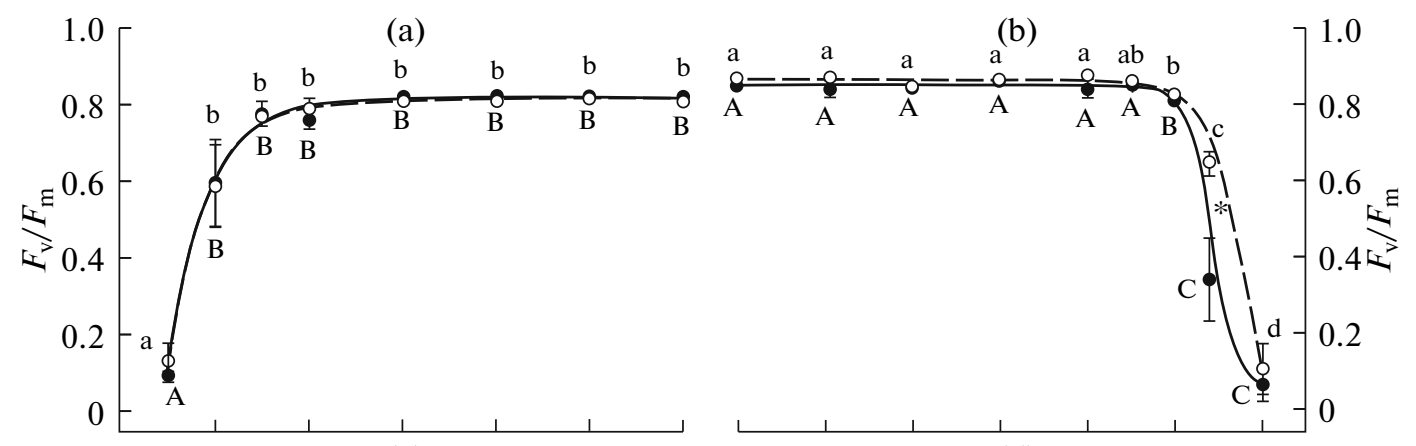

(c)
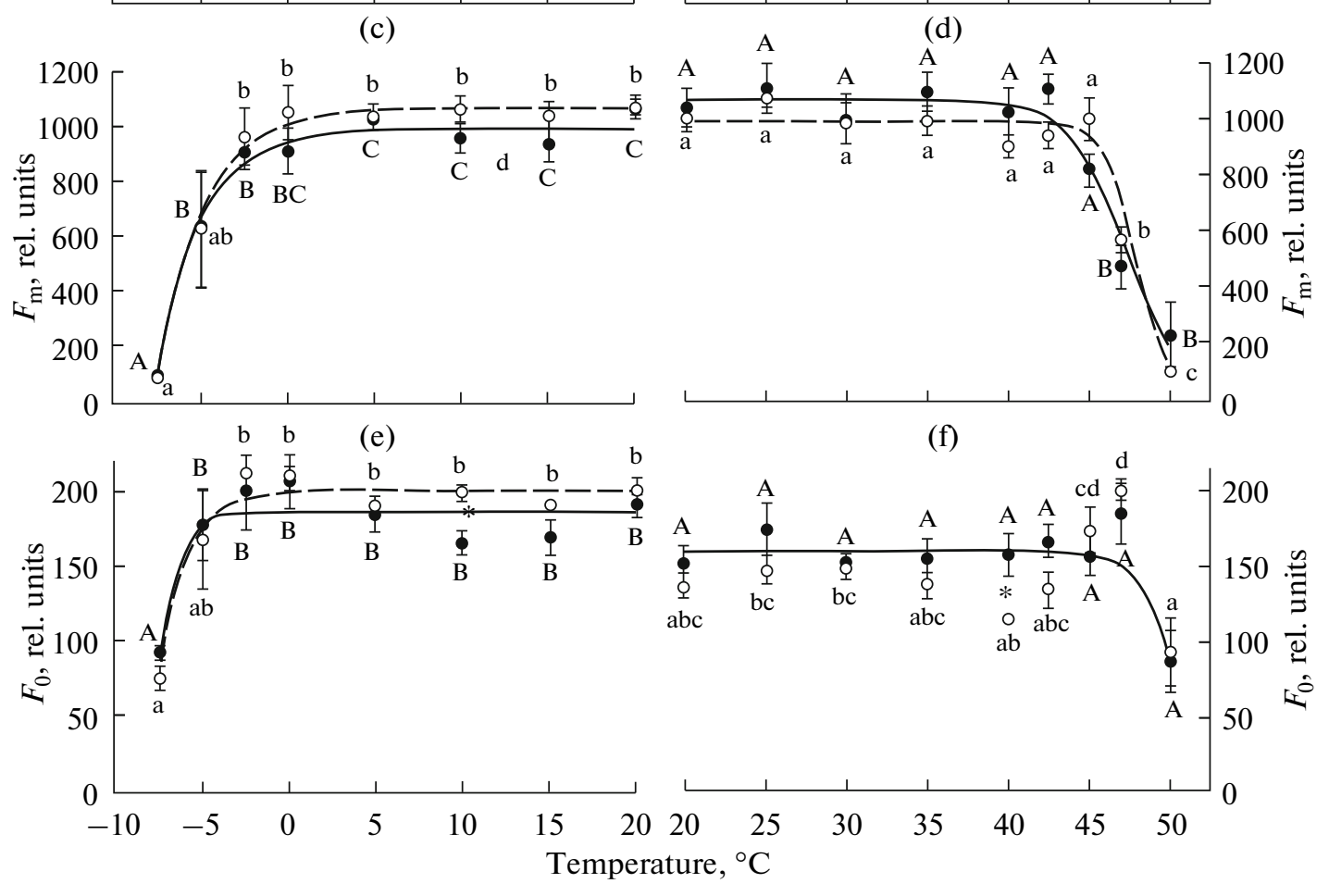

Fig. 2. Maximum quantum efficiency of PSII photochemistry $\left(\left(F_{\mathrm{v}} / F_{\mathrm{m}}(\mathrm{a}, \mathrm{b})\right)\right.$, maximum fluorescence $\left(\left(F_{\mathrm{m}}(\mathrm{c}, \mathrm{d})\right)\right.$, and basal fluorescence $\left(\left(F_{0}(\mathrm{e}, \mathrm{f})\right)\right.$ after a recovery period of $24 \mathrm{~h}$ after the treatment from +20.0 to $-7.5^{\circ} \mathrm{C}$ (left panels) and from +20.0 to $+50.0^{\circ} \mathrm{C}$ (right panels) for leaves of $L$. camara from the Galápagos Islands (white symbols; dotted line) and from the Southwest Iberian Peninsula (black symbols; continued line). Different coefficients (Iberian Peninsula: capital letters; Galápagos: lowercase letters) denote significant differences between treatments (ANOVA or Kruskal-Wallis, $P<0.05$ ) and asterisks denote differences between populations for the same temperature $(t$-test, $P<0.05)$. Data are means \pm SE.

photosynthetic apparatus in our experiments demonstrated a wide temperature tolerance range in darkness (from -2.5 to $+42.5^{\circ} \mathrm{C}$ ). Thus, its tolerance to low temperatures was higher than that of other species, such as pea (Pisum sativum) that was not able to recover after $+4.0^{\circ} \mathrm{C}[18]$ and the Mediterranean trees Juniperus oxicedrus, J. phoenicea, and Pinus pinea that showed a poor recovery capacity after $+10.0^{\circ} \mathrm{C}$ for $30 \mathrm{~min}$ [15]. The comparison between our results and field observations point out that L. camara would be especially sensitive to the synergic effects of low temperatures and high radiation levels, being much less sensitive to low temperatures in darkness.

L. camara showed optimal functioning of its PSII with very low photoinhibition levels $\left(F_{\mathrm{v}} / F_{\mathrm{m}}\right.$ between ca 0.750 and ca. 0.870 ) just after exposure to tempera- tures between -2.5 and $+35.0^{\circ} \mathrm{C}$ for the Iberian population and between +10.0 and $+25.0^{\circ} \mathrm{C}$ for the Galápagos population. The Iberian population maintained the same optimum temperature interval in $24 \mathrm{~h}$ after treatment (with maximum and constant $F_{\mathrm{v}} / F_{\mathrm{m}}$ and $P_{\mathrm{N}}$ ) as just after the temperature exposure. In contrast, the Galápagos population expanded its optimum temperature interval to -5.0 and $+42.5^{\circ} \mathrm{C}$ after recovery, showing $P_{\mathrm{N}}$ higher than $10 \mu \mathrm{mol} \mathrm{O}_{2} /\left(\mathrm{m}^{2} \mathrm{~s}\right)$ between $-5.0^{\circ} \mathrm{C}$ and $+47.5^{\circ} \mathrm{C}$. These $P_{\mathrm{N}}$ values were in the range of those reported for Iberian L. camara at $+23^{\circ} \mathrm{C}$ at open-air conditions $\left(10-15 \mu \mathrm{mol} \mathrm{CO} /\left(\mathrm{m}^{2} \mathrm{~s}\right)\right.$ [19]. These wide ranges of thermal tolerance occurred when plants were acclimated to summer or winter conditions and were exposed gradually to high or low 


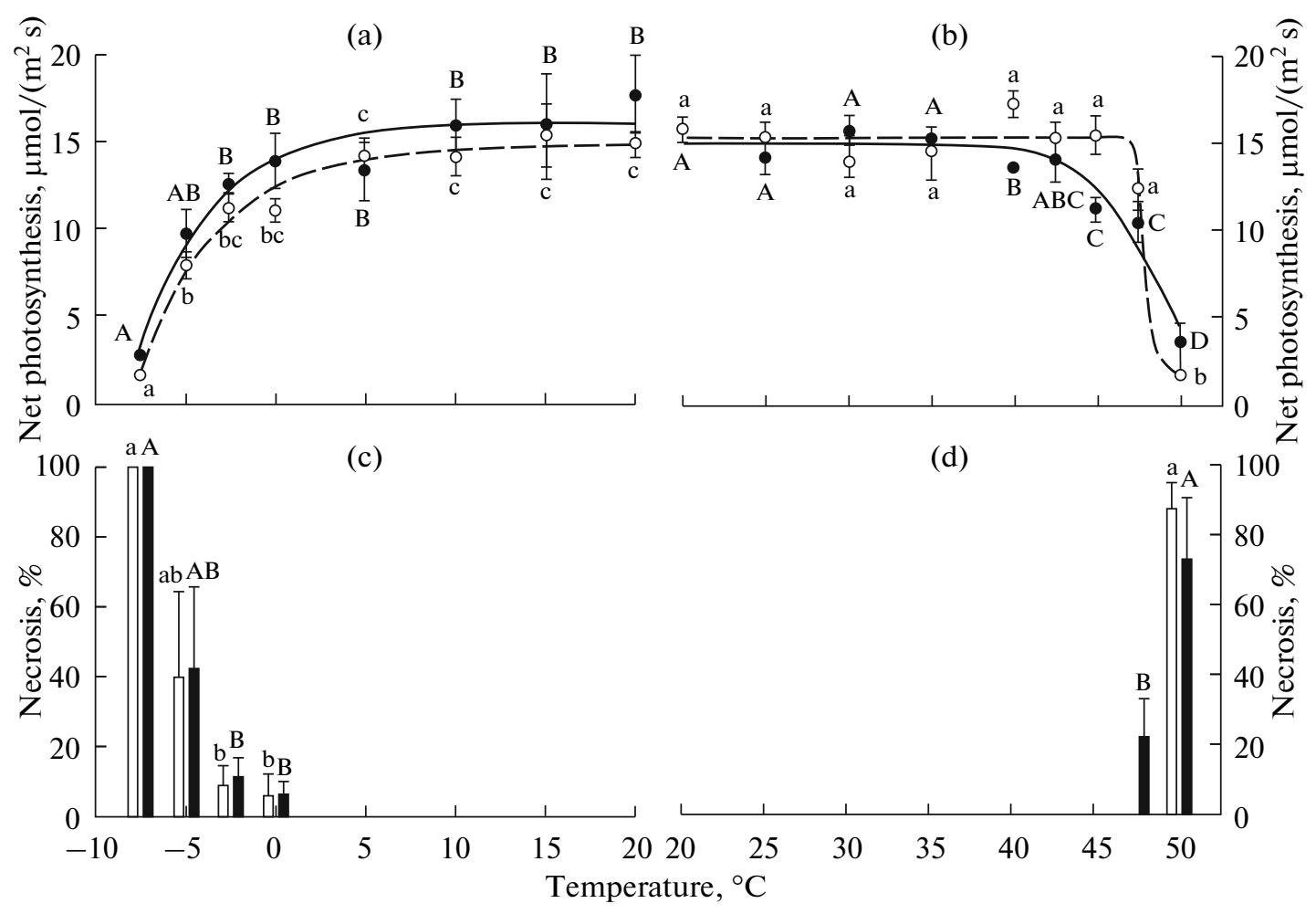

Fig. 3. Net photosynthesis rate (a, b) and necrosis percentage (c, d) after 24 h of recovery for leaves of L. camara from the Galápagos Islands (white symbols and dotted line) and from the Iberian Peninsula (black symbols and continued line), which the previous day during the winter were subjected to treatments of $30 \mathrm{~min}$ from +20.0 to $-7.5^{\circ} \mathrm{C}$ (left panels) and during the summer from +20.0 to $+50.0^{\circ} \mathrm{C}$ (right panels). Different coefficient (Iberian Peninsula: capital letters; Galápagos: lowercase letters) denote significant differences between treatments (ANOVA or Kruskal-Wallis, $P<0.05$ ) and asterisks denote significant differences between populations for the same temperature $(t$-test, $P<0.05)$. Data are means \pm SE.

temperatures, respectively, since acclimation is a key factor in the regulation of the thermal tolerance.

Just after exposure to low temperatures, gradual cold-induced photoinhibition was recorded for both populations, reflected in the lower $F_{\mathrm{v}} / F_{\mathrm{m}}$ as a consequence of a decrease in $F_{\mathrm{m}}$ with similar $F_{0}$ [20]. This photoinhibition, higher at below-zero temperatures, revealed deactivation of PSII reaction centers [21] preventing overexcitation of photosynthesis and oxidative damages [22]. Photoinhibition levels increased and $P_{\mathrm{N}}$ decreased gradually at temperatures lower than $-2.5^{\circ} \mathrm{C}$ in $24 \mathrm{~h}$ after the low temperature treatment. Low temperatures inhibit the rate of photosynthesis through limiting enzymatic rates of the Calvin cycle $[5]$ and also affecting diffusion processes in the electron transport chain [23]. The photoinhibition level in $24 \mathrm{~h}$ after the thermal treatment was much higher than just after the thermal treatment: for $-5.0^{\circ} \mathrm{C}$ ca. 0.600 vs. 0.700 and $-7.5^{\circ} \mathrm{C}$ ca. 0.100 vs. 0.600 . These low $F_{\mathrm{v}} / F_{\mathrm{m}}$ after $24 \mathrm{~h}$ together with low $F_{\mathrm{m}}, F_{0}$, and $P_{\mathrm{N}}$ (as low as ca. $\left.2.5 \mu \mathrm{mol} \mathrm{O}_{2} /\left(\mathrm{m}^{2} \mathrm{~s}\right)\right)$ reflected permanent damages to the photosynthetic apparatus [21]. In fact, the high necrosis percentages recorded for temperatures lower than $-2.5^{\circ} \mathrm{C}$ evidenced the disruption of structures and functions of cells and tissues by the freezing effect of large ice masses [24].
On the other hand, abrupt heat-induced photoinhibition was recorded for both populations from $+45.0^{\circ} \mathrm{C}$ onwards just after the thermal treatment, reflected in a sudden drop in $F_{\mathrm{v}} / F_{\mathrm{m}}$ due to decreasing $F_{\mathrm{m}}$ and increasing $F_{0}$. Pea plants showed similar responses with $F_{0}$ increasing from $+42.5^{\circ} \mathrm{C}$ onwards [18]. This has been interpreted as a reflection of reduced energy transport effectiveness from antenna chlorophyll $a$ to the reaction center of PSII [25] and/or directly due to the block of PSII reaction centers $[15,26]$. Leaves exposed to $+45 \cdot 0^{\circ} \mathrm{C}$ that showed high photoinhibition levels just after the thermal treatment $\left(F_{\mathrm{v}} / F_{\mathrm{m}}\right.$ ca. 0.500$)$ recovered completely after $24 \mathrm{~h}\left(F_{\mathrm{v}} / F_{\mathrm{m}}\right.$ ca. 0.800$)$, showing $P_{\mathrm{N}}$ between $12-$ $15 \mu \mathrm{mol} \mathrm{O}_{2} /\left(\mathrm{m}^{2} \mathrm{~s}\right)$. High temperatures may affect photosynthesis by altering the excitation energy distribution by changing the structure of thylakoids, by provoking excessive membrane fluidity, enhancing oxidative stress, and by changing the activity of the Calvin cycle and other metabolic processes, such as photorespiration [27], or may inhibit the repair of PSII (28). At higher temperatures $\left(>+47.5^{\circ} \mathrm{C}\right)$, low $F_{\mathrm{v}} / F_{\mathrm{m}}$ values after the recovery period $(<0.495)$, together with $P_{\mathrm{N}}$ values as low as ca. $2.5 \mu \mathrm{mol} \mathrm{O}_{2} /\left(\mathrm{m}^{2} \mathrm{~s}\right)$, denoted permanent damages to the photosynthetic apparatus. Furthermore, necrosis was also recorded at the highest 
temperatures coming from denaturation of membrane proteins or from melting of membrane lipids, which leads to membrane rupture and the loss of cellular contents [29].

Both populations of Lantana responded similarly to temperature treatments. Slight interpopulation differences were found only at extreme temperatures. $F_{\mathrm{v}} / F_{\mathrm{m}}$ just after the lowest thermal treatment at $-7.5^{\circ} \mathrm{C}$ was lower for the Galápagos than for the Iberian population. After $24 \mathrm{~h}$, this difference disappeared but $P_{\mathrm{N}}$ still indicated a better photosynthetic functioning for the Iberian than for the Galápagos population. On the other hand, the chlorophyll fluorescence dynamic of both populations was similar just after the exposure to high temperatures, but leaves from the Galápagos population subjected to $+47.5^{\circ} \mathrm{C}$ showed higher values of $F_{\mathrm{v}} / F_{\mathrm{m}}$ and $P_{\mathrm{N}}$ after $24 \mathrm{~h}$ than the Iberian population.

During day time, plants in the field are not only exposed to low or high temperatures but suffer frequently from synergetic effects of temperatures and high radiation intensities $[4,20]$. In these field conditions, excess energy must be dissipated or the chloroplast membranes sustain oxidative damages, which can lead to tissue and/or whole plant death [30], as has been reported in L. camara [11]. We worked in dark conditions, trying to emulate nocturnal chilling episodes, such as those recorded at L. camara northern and southern extremes of its geographical distribution range showing that it has a wide temperature tolerance, but this tolerance could be much narrower in field conditions where extreme temperatures coincide with high radiation levels. Thus, further studies are necessary to know the synergetic effects of both low and/or high temperatures with high radiation intensities, and the effect of more prolonged episodes of low and high temperatures on L. camara leaves.

\section{ACKNOWLEDGMENTS}

Thanks to Jesús and José of the Greenhouse of the University of Seville for their assistance and Raúl Serrano for his help in laboratory.

This research was supported by Agencia Española de Cooperación Internacional para el Desarrollo (AECID) through a grant to the first author.

\section{REFERENCES}

1. Hellmann, J.J., Byers, J.E., Bierwagen, B.G., and Dukes, J.S., Five Potential Consequences of Climate Change for Invasive Species, Conserv. Biol., 2008, vol. 22, pp. 534-543.

2. Berry, J. and Björkman, O., Photosynthetic Response and Adaptation to Temperature in Higher Plants, Annu. Rev. Plant Physiol., 1980, vol. 31, pp. 491-543.

3. Lichtenthaler, H.K., Vegetation Stress: An Introduction to the Stress Concept in Plants, J. Plant Physiol., 1996, vol. 148, pp. 4-14.
4. Adams, W.W., Demmig-Adams, B., Verhoeven, A.S., and Barker, D.H., "Photoinhibition" during Winter Stress: Involvement of Sustained Xanthophyll CycleDependent Energy Dissipation, Aust. J. Plant Physiol., 1994, vol. 22, pp. 261-276.

5. Stitt, M. and Hurry, V., A Plant for All Seasons: Alterations in Photosynthetic Carbon Metabolism during Cold Acclimation in Arabidopsis, Curr. Opin. Plant Biol., 2002, vol. 5, pp. 199-206.

6. Davidson, N.J., Battaglia, M., and Close, D.C., Photosynthetic Responses to Overnight Frost in Eucalyptus nitens and E. globulus, Trees, 2004, vol. 18, pp. 245252.

7. Powles, S.B., Photoinhibition of Photosynthesis Induced by Visible Light, Annu. Rev. Plant Physiol., 1984, vol. 35, pp. 15-44.

8. Day, M.D., Wiley, C.J., Playford, J., and Zalucki, M.P., Lantana Current Management Status and Future Prospects, Canberra: Australian Centre for International Agricultural Research, 2003.

9. Anon. National Strategy for Lantana Management, Brisbane: Queensland Department of Natural Resources, 2000.

10. Sharma, G.P., Raghubanshi, A.S., and Singh, J.S., Lantana Invasion: An Overview, Weed Biol. Manag., 2005, vol. 5, pp. 157-165.

11. Thakur, M.L., Ahmad, M., and Thakur, R.K., Lantana Weed (Lantana camara var. aculeata Linn) and Its Possible Management through Natural Insect Pests in India, Ind. For., 1992, vol. 118, pp. 466-488.

12. Tye, A., Invasive Plant Problems and Requirements for Weed Risk Assessment in the Galápagos Islands, Weed Risk Assessment, Groves, R.H., Panetta, F.D., and Virtue, J.G., Eds., Collingwood: CSIRO Publ., 2001, pp. 153-175.

13. McMullen, C.K., Flowering Plants of the Galapagos, Cornell: Cornell Univ. Press, 1999.

14. Castellanos, E.M., Figueroa, M.E., and Davy, A.J., Nucleation and Facilitation in Saltmarsh Succession: Interactions between Spartina maritima and Arthrocnemum perenne, J. Ecol., 1994, vol. 82, pp. 239-248.

15. Rubio-Casal, A.E., Leira-Doce, P., Figueroa, M.E., and Castillo, J.M., Contrasted Tolerance to Low and High Temperatures of Three Tree Taxa Co-Occurring on Coastal Dune Forests under Mediterranean Climate, J. Arid Environ., 2010, vol. 74, pp. 429-439.

16. Schreiber, U., Schliwa, W., and Bilger, U., Continuous Recording of Photochemical and Nonphotochemical Chlorophyll Fluorescence Quenching with a New Type of Modulation Fluorimeter, Photosynth. Res., 1986, vol. 10, pp. 51-62.

17. Bolhàr-Nordenkampf, H.R. and Öquist, G., Chlorophyll Fluorescence as a Tool in Photosynthesis Research, Photosynthesis and Production in a Changing Environment: A Field and Laboratory Manual, Hall, D.O., Scurlock, J.M.O., Bolhàr-Nordenkampf, H.R., Leegoog, R.C., and Long, S.P, Eds., London: Chapman \& Hall, 1993, pp. 193-206.

18. Georgieva, K. and Lichtenthaler, H.K., Photosynthetic Activity and Acclimation Ability of Pea Plants to Low and High Temperature Treatment as Studied by 
Means of Chlorophyll Fluorescence, J. Plant Physiol., 1999, vol. 155, pp. 416-423.

19. Carrión-Tacuri, J., Rubio-Casal, A.E., de Cires, A., Figueroa, M.E., and Castillo, J.M., Lantana camara L.: A Weed with Great Light-Acclimation Capacity, Photosynthetica, 2011, vol. 49, pp. 321-329.

20. Close, D.C., Beadle, C.L., Brown, P., and Holz, G.K., Cold-Induced Photoinhibition Affects Establishment of Eucalyptus nitens (Deane and Maiden) Maiden and Eucalyptus globulus Labill, Trees, 2000, vol. 15, pp. 32-41.

21. Maxwell, K. and Johnson, G.N., Chlorophyll Fluorescence - A Practical Guide, J. Exp. Bot., 2000, vol. 51, pp. 659-668.

22. Huner, N.P.A., Öquist, G., Hurry, V.M., Krol, M., Falk, S., and Griffith, M., Photosynthesis, Photoinhibition and Low Temperature Acclimation in Cold Tolerant Plants, Photosynth. Res., 1993, vol. 37, pp. 19-39.

23. Laisk, A. and Oja, V., Range of Photosynthetic Control of Post Illumination P700 $0^{ \pm}$Reduction Rate in Sunflower Leaves, Photosynth. Res., 1994, vol. 39, pp. 39-50.

24. Pearce, R.S., Plant Freezing and Damage, Ann. Bot., 2001, vol. 87, pp. 417-424.
25. Briantais, J., Vernotte, C., Krause, G., and Weis, E., Chlorophyll $a$ Fluorescence of Higher Plants: Chloroplasts and Leaves, Light Emission by Plant and Bacteria, Govindjee, Amesz, J., and Fork, D., Eds., New York: Academic, 1986, pp. 539-583.

26. Wen, X., Gong, H., and Lu, C., Heat Stress Induces an Inhibition of Excitation Energy Transfer from Phycobilisomes to Photosystem II but Not to Photosystem I in a Cyanobacterium Spirulina platensis, Plant Physiol. Biochem., 2005, vol. 43, pp. 389-395.

27. Yordanov, I., Response of Photosynthetic Apparatus to Temperature Stress and Molecular Mechanisms of Its Adaptation, Photosynthetica, 1992, vol. 26, pp. 517531.

28. Allakhverdiev, S.I., Kreslavskii, V.D., Klimov, V.V., Los, D.A., Carpentier, R., and Mohanty, P., Heat Stress: An Overview of Molecular Responses in Photosynthesis, Photosynth. Res., 2008, vol. 98, pp. 541-550.

29. Ahrens, M.J. and Ingram, D.L., Heat Tolerance of Citrus Leaves, Hort. Sci., 1988, vol. 23, pp. 747-748.

30. Foyer, C., Lelandais, M., and Kunert, K.J., Photooxidative Stress in Plants, Physiol. Plant., 1994, vol. 92, pp. 696-717. 